Darko Matovac

UDK 811.163.42'243:81'367.4

Filozofski fakultet, Sveučilište u Zagrebu

Hrvatska

dmatovac@ffzg.hr
DOI: 10.4312/vestnik.11.151-171

\title{
TREBA LI POUČAVATI REDOSLIJEDU PRIDJEVNIH MODIFIKATORA U SLOŽENOJ IMENSKOJ SKUPINI?
}

UVOD

Opis redoslijeda sastavnica složene imenske skupine, a posebice opis redoslijeda pridjevnih modifikatora, sastavni je dio gramatika mnogih jezika (npr. Quirk i ostali 1985; Eastwood 2002; Downing i Locke 2006; Engel 1996; Eisenberg 2013; RAE 2010), a toj se temi pozornost redovito posvećuje i u gramatikama namijenjenima neizvornim govornicima kao i u priručnicima za poučavanje jezika. U gramatikama hrvatskoga (npr. Barić i ostali 1997; Silić i Pranjković 2005; Raguž 1997) pak o tome se ne govori detaljnije, a u kontekstu poučavanja hrvatskoga kao drugog i stranog jezika (HJ2) tomu se pozornost uopće ne posvećuje. Može se stoga zapitati imaju li uopće govornici HJ2 odstupanja pri usvajanju znanja o nizanju pridjevnih modifikatora u složenim imenskim skupinama te, posljedično, treba li ih tomu uopće izravno poučavati. Ovdje se prikazuje istraživanje osmišljeno da bi se dobili odgovori na ta pitanja. Kreće se od pretpostavke da bi govornike HJ2 trebalo poučavati nizanju pridjevnih modifikatora u složenim imenskim skupinama ako se pokaže da u tome imaju odstupanja. Ako se, pak, pokaže da u nizanju pridjevnih modifikatora nemaju odstupanja, a tomu nisu poučavani, može se pretpostaviti ili da je taj redoslijed u njihovim materinskim jezicima isti kao i u hrvatskome ili da je načelo nizanja pridjevnih modifikatora svojevrsna jezična univerzalija.

\section{2}

\section{REDOSLIJED SASTAVNICA SLOŽENE IMENSKE SKUPINE U HRVATSKOME}

O redoslijedu sintaktičkih komponenata, pa tako i o redoslijedu sastavnica složene imenske skupine, u gramatikama hrvatskoga ne govori se iscrpno, a, primjećuje Marković (2010: 233), „kadšto promaknu i elementarne pogreške“. Za potrebe ovoga istraživanja najprimjerenijom se pokazala rasprava koju donose Belaj i Kuna (2013) te Belaj i Tanacković 
Faletar (2014). ${ }^{1} \mathrm{U}$ njoj se redoslijed sastavnica složene imenske skupine opisuje unutar teorijskog okvira kognitivne gramatike (Langacker 1987; Langacker 1991; Langacker 2008), što znači da se kreće od pretpostavke da je redoslijed sastavnica složene imenske skupine snažno, a, kako se u zaključku tvrdi, vjerojatno i isključivo, značenjski motiviran.

Kao temeljni čimbenik koji uvjetuje redoslijed sastavnica imenske skupine Belaj i Kuna (2013) te Belaj i Tanacković Faletar (2014) navode referenciju, tj. usidrenje (en. grounding), koju određuju kao uspostavljanje mentalnog kontakta sudionika govornog čina s referentom imenske skupine. Značenjska izgradnja imenske skupine kreće od imenice, koja se značenjski može opisati kao potencijalna veličina ili tip (en. type), tj. može se reći da ona označava tek mogući referent. Taj mogući referent može se specificirati, tj. modificirati dodavanjem pridjevnih premodifikatora, npr. zelena stara stolica, no takva složena imenska skupina, sve dok nije postavljena u kontekst, i dalje je tek potencijalna veličina, tj. nešto što nije, no ima mogućnost biti konkretizirano u kontekstu. Referencija na stvaran referent, tj. upućivanje na aktualnu veličinu ili varijantu (en. token), a što je preduvjet uspješne komunikacije, postiže se tek smještanjem imenske skupine u kontekst i upotrebom različitih implicitnih ili eksplicitnih sredstava usidrenja, a koji su elementi daljnje značenjske izgradnje imenske skupine. Usidrenje bi se najjednostavnije moglo opisati kao konkretizacija, jedinstveno identificiranje onog na što se imenica u imenskoj skupini odnosi, tj. usidrenje se može opisati kao proces kojim se uspostavlja jedinstvena mentalna poveznica između imenice i referenta na koji se odnosi, tako da ta veza bude jasna i govorniku i sugovorniku. Pojednostavljeno, usidrenjem imenske skupine govornik daje do znanja sugovorniku na što misli, a sugovornik zahvaljujući jezičnim sredstvima usidrenja može shvatiti na što govornik misli. Prvi korak u usidrenju imenske skupine apsolutna je kvantifikacija brojevima, npr. tri zelene stare stolice. Ipak, brojevi tek djelomično usidravaju imensku skupinu jer ne referiraju izravno na konkretne, jedinstveno identificirane referente, već tek implicitno, kroz određivanje broja referenata unutar skupine referenata, pretpostavljaju realizaciju tih referenata. Daljnji i konačni korak u izgradnji značenjske strukture imenske skupine usidrenje je imenske skupine eksplicitnim sredstvima determinacije, a u hrvatskom su to determinatori, relativni kvantifikatori i neodređeni djelomični apsolutni kvantifikatori. U konačnici se značenjska izgradnja imenske skupine može prikazati na sljedeći način: TIP (modifikatori + imenica) > VARIJANTA (apsolutni kvantifikatori + TIP) > USIDRENA VARIJANTA (determinatori, relativni kvantifikatori, neodređeni djelomični apsolutni kvantifikatori + VARIJANTA/TIP).

Tablica 1 kreće od rasprave koju donose Belaj i Kuna (2013) te Belaj i Tanacković Faletar (2014) te pokušava sažeto prikazati redoslijed sastavnica složene imenske skupine

1 Vrlo vrijedna je i Palićeva (2015) rasprava u kojoj se donosi kratak pregled različitih pristupa opisu redoslijedu pridjevnih modifikatora te se te se taj redoslijed opisuje funkcionalnim modelom, a koji pretpostavlja da se imenska skupina sastoji od triju funkcionalnih zona (kategorizacijske, specifikacijske i intenzifikacijske). Prema tom modelu u imenskoj skupini imenici prvo prethode pridjevi s intenzifikacijskom funkcijom, npr. čisti, pravi, slijede pridjevi kojima se specificiraju subjektivnija svojstva, npr. zanimljiv, divan, pa pridjevi kojima se specificiraju objektivnija svojstva, npr. nov, plav, te, u konačnici, pridjevi koji klasificiraju označeno imenicom, npr. lovački, politički. 
u hrvatskome (uz dodatnu napomenu da se u imenskoj skupini može pojaviti samo jedan apsolutni kvantifikator te jedan posvojni determinator), a primjeri u osnovnim crtama oprimjeruju ta pravila. Potrebno je, međutim, dodati da postoji niz nedovoljno objašnjenih ograničenja u kombiniranju i zamjeni položaja različitih sredstava usidrenja, a čemu svakako treba posvetiti dodatna istraživanja, posebice korpusna, koja bi mogla izravnije ukazati na određene obrasce.

Tablica 1: Redoslijed sastavnica složene imenske skupine u hrvatskome

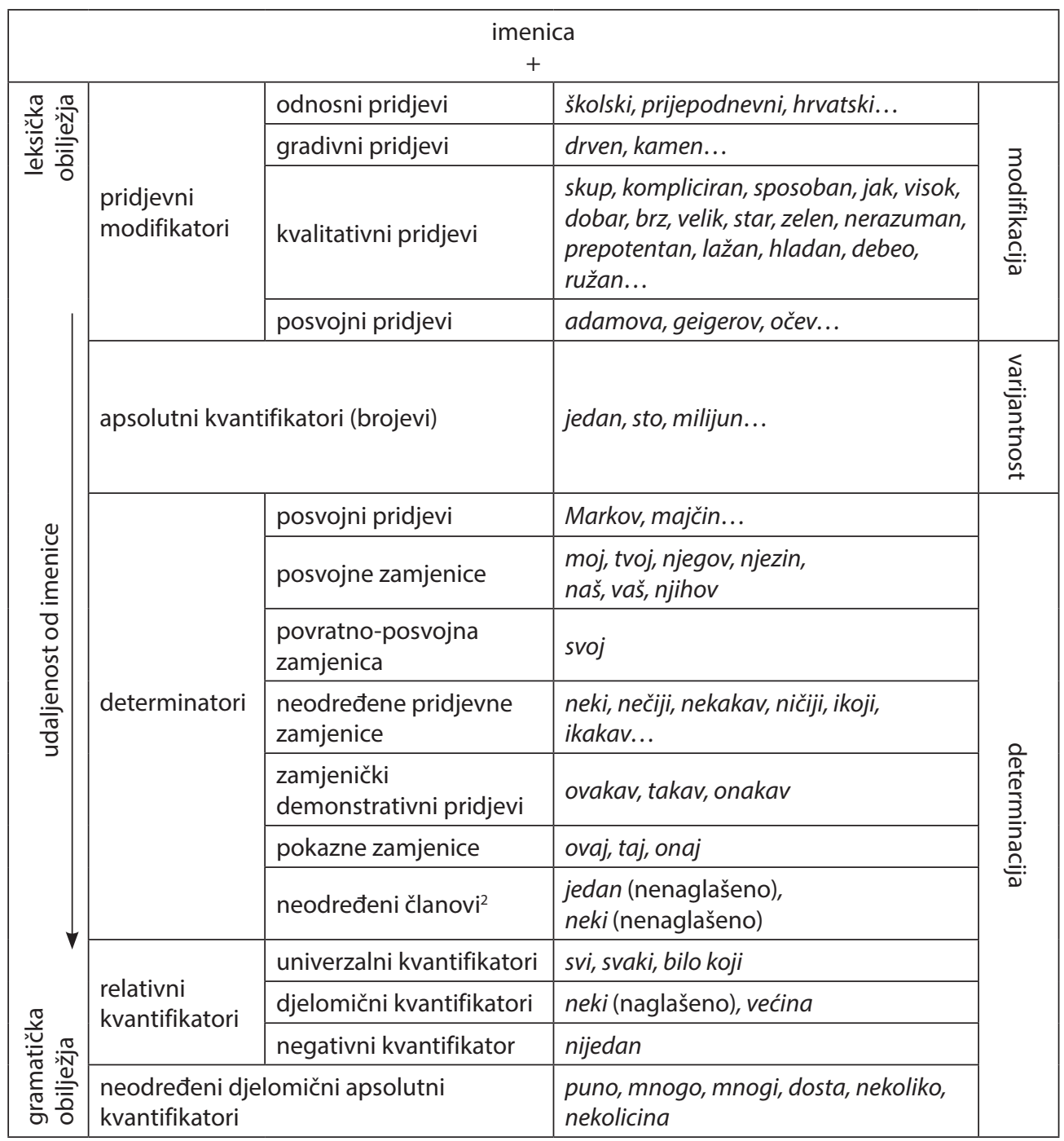

2 O neodređenim članovima u hrvatskom više govore Belaj i Matovac (2015) te Belaj i Tanacković Faletar (2014). 
a) sve | te takve moje | stare školske | prijateljice

relativni kvantifikator | determinatori | modifikatori | imenica

b) nekolicina $\mid$ tih $\mid$ nerazumnih hrvatskih | navijača

neodređeni apsolutni kvantifikator | determinator | modifikatori | imenica

c) svih $\mid$ tih očevih $\mid$ pet $\mid$ starih $\mid$ prijatelja

relativni kvantifikator | determinatori | apsolutni kvantifikator | modifikator | imenica

d) većina $\mid$ tih $\mid$ prepotentnih $\mid$ političara

relativni kvantifikator | determinator | modifikator | imenica

e) jedan njegov $\mid$ stari školski $\mid$ prijatelj

determinatori | modifikatori | imenica

f) mnogo $\mid$ takvih njegovih $\mid$ lažnih | obećanja

neodređeni djelomični apsolutni kvantifikator | determinatori | modifikator | imenica

g) svih $\mid$ tih $\mid$ pet $\mid$ zmijski hladnih $\mid$ piva

relativni kvantifikator | determinator | apsolutni kvantifikator | modifikator | imenica

h) puno $\mid$ tih takvih $\mid$ velikih debelih ružnih $\mid$ štakora

neodređeni djelomični apsolutni kvantifikator | determinatori | modifikatori | imenica

\section{REDOSLIJED PRIDJEVNIH MODIFIKATORA U SLOŽENOJ IMENSKOJ SKUPINI U HRVATSKOME}

Kada je riječ o redoslijedu pridjevnih modifikatora u odnosu na imenicu, u hrvatskome oni prethode imenici, a iznimka su tek neka imena, termini, ustaljeni izrazi ili poetski izričaji, npr. Karlo Veliki, plavac mali, Matica hrvatska, bezobraznica bezobrazna i sl. Hrvatski, dakle, ne slijedi 19. Greenbergovu univerzaliju prema kojoj jezici u kojima opisni pridjevi slijede imenicu mogu imati nekoliko izuzetaka u kojima pridjev prethodi imenici, dok u jezicima u kojima pridjev prethodi imenici izuzetaka u kojima bi pridjev slijedio imenicu nikada nema. Što se tiče općeg načela redoslijeda sastavnica složene imenske skupine u hrvatskom, ono je u suglasnosti s 20. Greenbergovom jezičnom univerzalijom u kojoj se tvrdi da će se u jeziku u kojem demonstrativi, brojevi i opisni pridjevi prethode imenici oni uvijek nalaziti u redoslijedu kojim su navedeni, a ako pak slijede imenicu, redoslijed će biti isti ili potpuno suprotan (Greenberg 1966: 87).

U načelu u hrvatskome pridjevnih modifikatora, a kojima pripadaju odnosni, gradivni i kvalitativni pridjevi, ispred imenice nema više od tri, a to ograničenje u broju pridjevnih modifikatora može se smatrati i svojevrsnom jezičnom univerzalijom (Belaj i Kuna 2013: 318; Marković 2010: 54). Slika (1), koja potvrđuje navedeno, prikazuje učestalost imenskih skupina s više od jednog pridjevnog modifikatora u hrvatskome prema korpusu $h r W a C$. 


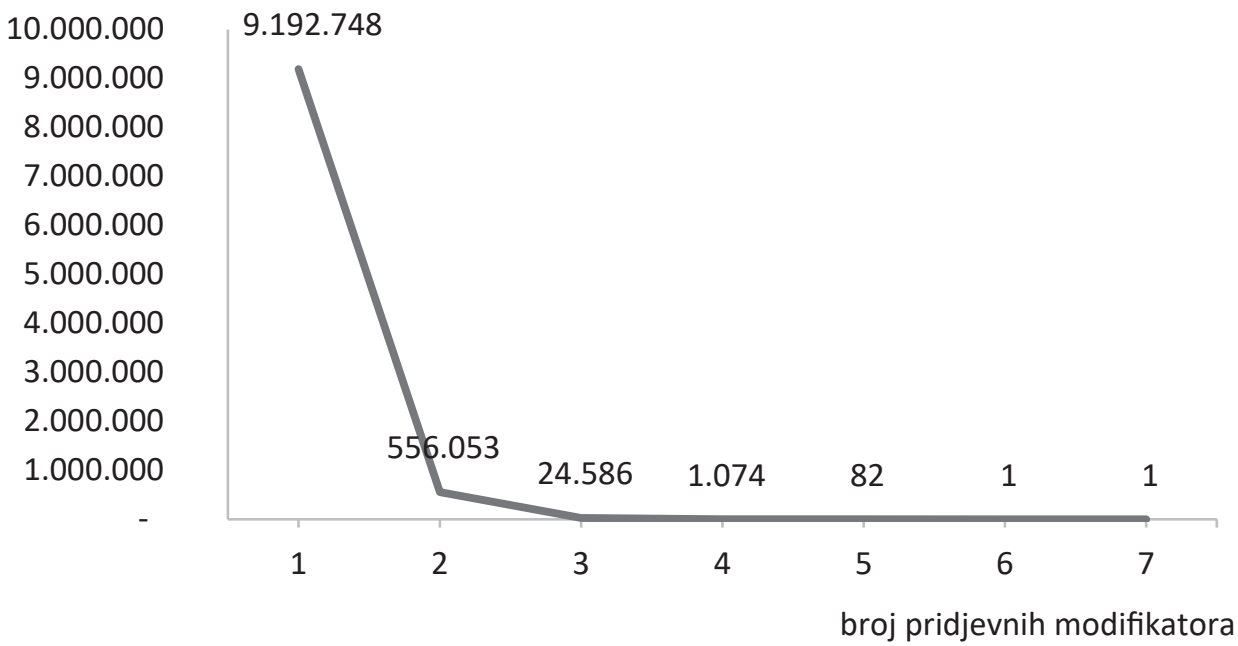

Slika 1: Učestalost imenskih skupina s više od jednog pridjevnog modifikatora u korpusu hrWaC

O redoslijedu kojim se unutar složene imenske skupine nižu odnosni, gradivni i kvalitativni pridjevi u gramatikama hrvatskoga ne govori se detaljnije, ${ }^{3}$ često se nižu primjeri bez usustavljivanja ili objašnjavanja, ponekad se čak ni ne naznačuje da bi u navedenom moglo biti pravilnosti. S druge pak strane, u gramatikama drugih jezika redoslijed pridjevnih modifikatora sastavni je dio opisa imenske skupine, a objašnjava se, u pravilu, značenjskim obilježjima pridjeva.

Značenjskom klasifikacijom pridjeva u hrvatskome detaljnije se bavio Marković (2010; 2012) koji je, prilagodivši Dixonovu (2004: 3) podjelu, pridjeve podijelio u 13 značenjskih skupina, kako je prikazano u tablici 2. Marković (2010; 2012) je ukazao i na potrebu primjene te klasifikacije na opisivanje redoslijeda pridjevnih modifikatora $\mathrm{u}$ složenoj imenskoj skupini.

3 Barić i ostali (1997: 586) navode, primjerice, da u slučaju kad se uz neku riječ uvrštava više pridjeva u službi atributa, pridjevi šireg značenja prethode onima užeg značenja, no ne preciziraju dalje. Silić i Pranjković (2005: 236) također navode da redoslijed sastavnica imenske skupine ovisi o širini značenja riječi, no ne govore detaljnije o redoslijedu kvalitativnih pridjeva („Na prvome je mjestu član koji je značenjem širi od riječi na drugom mjestu, na drugome mjestu - član koji je širi od značenja riječi na trećem mjestu itd. Tako je atribut predstavljen odnosnim (relativnim) pridjevom značenjem širi od atributa predstavljenog posvojnim (posesivnim) pridjevom, atribut predstavljen posvojnim (posesivnim) pridjevom značenjem širi od značenja atributa predstavljenog razlikovnim (diferencijalnim) pridjevom, a atribut predstavljen razlikovnim (diferencijalnim) pridjevom značenjem širi od značenja predstavljenog kakvoćom (kvalitativnim pridjevom)." (Silić i Pranjković 2005: 365)). Redoslijedom pridjevnih modifikatora bavio se i Silić (1984), no bez detaljnijih značenjskih raščlambi. 
Tablica 2: Značenjske skupine pridjeva u hrvatskome prema Markoviću (2010: 88-91)

\begin{tabular}{|l|l|}
\hline DIMENZIJA & velik, malen, debeo, širok... \\
\hline DOB & star, mlad, nov... \\
\hline VRIJEDNOST, SLOŽENOST I KVALIFIKACIJA & dobar, loš, jednostavan, normalan... \\
\hline BOJA & crven, bijel, žut... \\
\hline FIZIČKO ITJELESNO ISKUSTVO & tvrd, mokar, hladan, zdrav, bolestan... \\
\hline LJUDSKA OSOBINA & sretan, pametan, okrutan, sramežljiv... \\
\hline BRZINA & spor, brz... \\
\hline SLIČNOST & različit, drugačiji, isti... \\
\hline KVANTIFIKACIJA & sav, cio, dovoljan... \\
\hline PROSTORNI IVREMENSKI POLOŽAJ & gornji, donji, sutrašnji... \\
\hline REDNI BROJEVI & prvi, stoti... \\
\hline POSVOJNOST I ODNOS & Markov, hrvatski... \\
\hline GRADIVNOST & drven, plastičan... \\
\hline
\end{tabular}

Belaj i Kuna (2013) te Belaj i Tanacković Faletar (2014), imajući na umu tu značenjsku klasifikaciju pridjeva, no ne uzimajući je cijelu u obzir (posvojne pridjeve izdvajaju iz skupine modifikatora, o rednim bojevima, pridjevima koji izražavaju sličnost i o pridjevima koji označavaju prostorni i vremenski položaj ne govore ništa, a kvantifikaciju izdvajaju iz modifikacije), navode da će redoslijed pridjevnih modifikatora u složenoj imenskoj skupini u hrvatskome biti kao što je prikazano na slici 2.

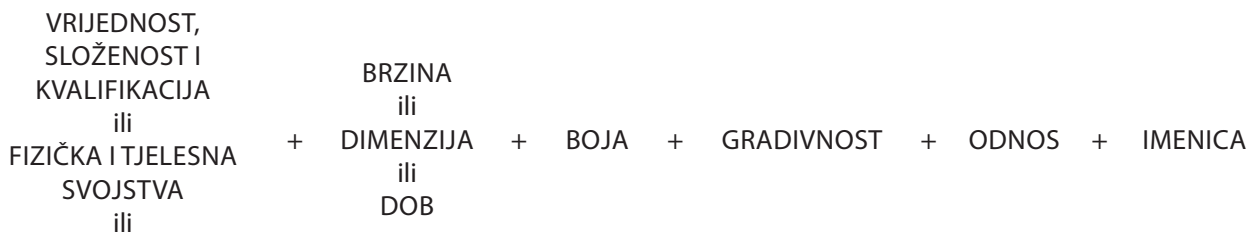

LJUDSKE OSOBINE

Slika 2: Redoslijed pridjevnih modifikatora u složenoj imenskoj skupini prema Belaju i Kuni (2013) te Belaju i Tanackoviću Faletaru (2014)

Riječ je o tipičnom, uobičajenom, neobilježenom redoslijedu. Zamjene redoslijeda pridjevnih modifikatora su moguće, a u pravilu rezultiraju manje prihvatljivim konstrukcijama, npr. zamjena mjesta gradivnog i odnosnog pridjeva u primjerima drvene školske klupe i ?školske drvene klupe. Zamjena mjesta neposredno susjednih kategorija na slici 2 rezultira manje neprihvatljivim konstrukcijama nego zamjena kategorija koje nisu neposredni susjedi. Kod pridjeva koji označavaju subjektivnije kategorije, tj. unutar skupine 
pridjeva koji označavaju BRZINU ili DIMENZIJU ili DOB ili pak unutar skupine pridjeva koji označavaju VRIJEDNOST, SLOŽENOST i KVALIFIKACIJU ili FIZIČKA I TJELESNA SVOJSTVA ili LJUDSKE OsoBINE Belaj i Kuna (2013) te Belaj i Tanacković Faletar (2014) nisu uočili učestalije obrasce nizanja unutar skupine, no naglašavaju da te skupine ne mogu međusobno slobodno zamjenjivati položaje, kao što ne mogu zamjenjivati položaj ni s pridjevima koji označavaju BoJU. Svakako, potrebno je napraviti daljnja istraživanja, posebice na opsežnijim korpusima, kako bi se uočilo postoje li dodatni obrasci nizanja pridjevnih modifikatora, posebice kvalitativnih, kao i uvjeti zamjene njihova redoslijeda.

Belaj i Kuna (2013) te Belaj i Tanacković Faletar (2014) kao temeljni čimbenik koji utječe na blizinu pridjevnog modifikatora imenici, slično kao npr. Eastwood (2002) ili Downing i Locke (2006), ističu postojanost i nepromjenjivost svojstva koje se tim pridjevnim modifikatorom imenici pripisuje, što se pak može povezati s općim jezičnim načelom blizine/udaljenosti - što je neko svojstvo nepromjenjivije obilježje nekog objekta, to su konceptualno oni bliži (Radden i Dirven 2007). Primjerice, boja nekog objekta u pravilu je slabije ili sporije promjenjiva od njegova oblika ili vrijednosti koja mu je pripisana, a podatak da je neki objekt načinjen od metala sigurno nije promjenjiv, dok podatak o njegovoj brzini jest i sl. Nadalje, činjenica da su pridjevi koji označavaju волU bliže imenici od, primjerice, pridjeva koji označavaju LJUDSKE OSOBINE i VRIJEDNOST može se objasniti time što je boja fizičko, objektivno svojstvo imeničkog referenta, dok su primjerice ljudske osobine i vrijednosti podložnije subjektivnosti i kulturološkim uvjetovanostima. Drugačije rečeno, redoslijed pridjeva uvjetovan je i hijerarhijom KONKRETNO > APSTRAKTNO. Nadalje, činjenica da nepromjenjivost svojstva označenog pridjevom, a podatak o nepromjenjivost svojstva objekta proizlazi iz percepcije tog objekta $i$ iskustva interakcije s tim objektom, utječe na redoslijed pridjeva u složenoj imenskoj skupini dokaz je kognitivnolingvističkog teorijskog polazišta da je jezik uvjetovan tjelesnim iskustvom.

\section{4 \\ KORPUSNA PROVJERA REDOSLIJEDA PRIDJEVNIH MODIFIKATORA U SLOŽENOJ IMENSKOJ SKUPINI U HRVATSKOME}

Tvrdnje o redoslijedu pridjevnih modifikatora u složenoj imenskoj skupini u hrvatskome koje donose Belaj i Kuna (2013) te Belaj i Tanacković Faletar (2014), a koje su prikazane na slici 2, provjerene su na 500 složenih imenskih skupina s dva pridjevna modifikatora (uzorak je prikupljen pretraživanjem Hrvatskog nacionalnog korpusa 3.0). Iako je riječ o relativno malenom uzorku, rezultati, koji potvrđuju tvrdnje, mogu se smatrati relevantnima budući da je riječ o prvom takvom korpusnom istraživanju. Analizirano je 100 primjera u kojima je pridjev koji izražava oDNos smješten neposredno uz imenicu, 100 primjera u kojima je pridjev koji izražava GRADIVNOST smješten neposredno uz imenicu itd. Odabrano je po pet najčešćih pridjeva koji označavaju oDNOS, GRADIVNOST itd. Rezultati su prikazani u tablici 3 tako da je prikazano koliko puta značenjska skupina u nekom 
stupcu prethodi imenskoj skupini koja se sastoji od imenice i pridjeva koji pripada značenjskoj skupini navedenoj u posljednjem stupcu. Primjerice, imenskim skupinama tipa ekonomski fakultet, ljudski rad ili turistički proizvod (riječ je o imenskoj skupini u kojoj imenici prethodi pridjev koji označava oDNos) u 42 primjera prethodi pridjev koji označava oDNOs, 9 puta pridjev koji označava BRZINU, DIMENZIJU ili DOB te 46 puta pridjev koji označava VRIJEDNOST, SLOŽENOST I KVALIFIKACIJU ili FIZIČKA I TJELESNA SVOJSTVA ili LJUDSKE OSOBINE. Na primjeru značenjske skupine pridjeva koji označavaju BoJU, može se primjerice vidjeti da njima, očekivano, prethode pridjevi koji označavaju VRIJEDNOST, SLOŽENOST I KVALIFIKACIJU ili FIZIČKA I TJELESNA SVOJSTVA ili LJUDSKE OSOBINE te pridjevi koji označavaju BRZINU, DIMENZIJU ili DOB, no da u manjem broju primjera tim pridjevima prethode pridjevi koji označavaju ODNOS, a pridjevi koji označavaju GRADIVNOST u prikupljenim primjerima uopće se ne pojavljuju ispred pridjeva koji označavaju BoJU. Potrebno je istaknuti da to što se ti pridjevi ne pojavljuju u analiziranom korpusu ne znači da takvih primjera nema, no, kao što Belaj i Kuna (2013) te Belaj i Tanacković Faletar (2014) primjećuju, primjeri tipa?drveni smeđi barokni stolovi upitne su prihvatljivosti.

Tablica 3: Redoslijed pridjevnih modifikatora u 500 složenih imenskih skupina prikupljenih iz Hrvatskog nacionalog korpusa 3.0

\begin{tabular}{|c|c|c|c|c|c|c|}
\hline \multicolumn{5}{|c|}{ prvi modifikator } & \multirow[b]{2}{*}{$\begin{array}{c}\text { drugi } \\
\text { modifikator }\end{array}$} & \\
\hline $\begin{array}{l}\text { VRIJEDNOST, SLOŽENOST I } \\
\text { KVALIFIKACIJA ili FIZIČKA } \\
\text { ILI TJELESNA SVOJSTVA ili } \\
\text { LJUDSKE OSOBINE }\end{array}$ & $\begin{array}{l}\text { BRZINA ili } \\
\text { DIMENZIJA } \\
\text { ili DOB }\end{array}$ & BOJA & GRADIVNOST & ODNOS & & $\stackrel{\frac{\nu}{2}}{2}$ \\
\hline 46 & 9 & 2 & 1 & 42 & ODNOS & \\
\hline 47 & 29 & 1 & 0 & 23 & GRADIVNOST & \\
\hline 50 & 11 & 11 & 2 & $26^{4}$ & BOJA & \\
\hline 86 & 9 & 0 & 0 & 5 & $\begin{array}{c}\text { BRZINA ili } \\
\text { DIMENZIJA ili } \\
\text { DOB }\end{array}$ & \\
\hline 96 & 4 & 0 & 0 & 0 & $\begin{array}{l}\text { VRIJEDNOST, } \\
\text { SLOŽENOST I } \\
\text { KVALIFIKACIJA } \\
\text { ili FIZIČKA } \\
\text { ili TJELESNA } \\
\text { SVOJSTVA } \\
\text { ili LJUDSKE } \\
\text { OSOBINE }\end{array}$ & \\
\hline
\end{tabular}

4 U slučaju kada pridjevima koji označavaju BOJU ili BRZINU, DIMENZIJA ili DOB prethode pridjevi koji označavaju ODNOS, u pravilu se, kada se radi o prikupljenim primjerima, riječ je o primjerima u kojima su ti pridjevi dijelom imena ili termina, npr. riječki Novi list i engleski crni čaj. 
Cilj istraživanja predstavljenoga u ovom radu pružiti je odgovore na sljedeća pitanja: (1) imaju li govornici HJ2 odstupanja pri nizanju pridjevnih modifikatora u složenim imenskim skupinama, tj. prate li opisana pravila o redoslijedu pridjevnih modifikatora ili od njih odstupaju i proizvode izvornim govornicima neprihvatljive ili manje prihvatljive konstrukcije, te, posljedično, (2) treba li ih uopće poučavati pravilnom redoslijedu pridjevnih modifikatora u složenim imenskim skupinama. Ako se pokaže da govornici HJ2 imaju odstupanja pri nizanju pridjevnih modifikatora, to znači da bi ih se redoslijedu pridjevnih modifikatora trebalo sustavno i eksplicitno poučavati, što sada nije slučaj. Ako se pokaže da govornici HJ2 nemaju odstupanja pri nizanju pridjevnih modifikatora, a tomu ih nitko nije sustavno poučio, može se pretpostaviti da je redoslijed pridjevnih modifikatora u njihovim materinskim jezicima isti kao i u hrvatskome, a u konačnici i pretpostaviti da je o temeljnom načelu nizanja pridjevnih modifikatora, a ovdje se zauzima stava da je riječ o značenjskoj uvjetovanosti, moguće misliti kao o svojevrsnoj jezičnoj univerzaliji.

Polazišna hipoteza je ta da govornici HJ2 nemaju odstupanja pri nizanju pridjevnih modifikatora u složenim imenskim skupinama, a tako je oblikovana zbog toga što se trenutačno u priručnicima za učenje HJ2 taj redoslijed ne objašnjava (npr. Čilaš Mikulić i ostali 2006; Kosovac i Lukić 2011; Barešić 2010), a poučavatelji HJ2 u ne navode da govornici HJ2 imaju sustavna odstupanja.

\section{6} METODOLOGIJA ISTRAŽIVANJA

Istraživanje je provedeno na 49 ispitanika tijekom zimskog semestra akademske godine 2016./2017.- od toga 29 ispitanika na razini A1.15 poznavanja HJ2, 10 ispitanika na razini B2.2 poznavanja HJ2 te 10 izvornih govornika hrvatskoga. Izvorni govornici bili su kontrolna skupina, izabrani su nasumično te nisu bili jezični stručnjaci, dok su ostali ispitanici bili polaznici Croaticuma - Centra za hrvatski kao drugi i strani jezik na Filozofskom fakultetu Sveučilišta u Zagrebu. Kada je riječ o ispitanicima na A1.1 razini poznavanja HJ2, njihovi prvi jezici većinom su indoeuropski jezici, uz znatan udio španjolskoga. Kada je riječ o ispitanicima na B2.2 razini poznavanja HJ2, njihovi prvi jezici su indoeuropski jezici. Ispitanici na razini A1.1 poznavanja HJ2 izabrani su kao ispitanici u ovom istraživanju jer nisu bili izloženi hrvatskome dugo i nisu mogli usvojiti redoslijed pridjeva. Oni su tek počinjali učiti pridjeve pa se moglo pretpostaviti da, ako nemaju odstupanja pri nizanju pridjevnih modifikatora, to može objasniti samo time što je i u njihovim materinskim jezicima redoslijed pridjevnih modifikatora isti. Ispitanici na razini B2.2 poznavanja HJ2 izabrani su kao ispitanici u ovom istraživanju da bi se vidjelo

5 Riječ je o razinama poznavanja jezika prema Zajedničkom europskom referentnom okviru za jezike. 
koliko se znanje o redoslijedu pridjevnih modifikatora poboljšava usvajanjem jezika, tj. da bi se vidjelo je li potrebno i eksplicitno poučavanje.

Za potrebe istraživanja razvijen je upitnik koji se sastoji od 56 pitanja podijeljenih $\mathrm{u}$ 4 zadatka. Razvijena je A i B serija upitnika da bi se isključila mogućnost da navođenje pridjeva u upitniku utječe na njihovo nizanje u odgovorima. Pitanja unutar zadatka poslagana su nasumičnim redom. Budući da je dio ispitanika bio na razini A1.1 poznavanja HJ2, tj. budući da je riječ o početnicima koji HJ2 uče tek mjesec dana, upitnik je sastavljen tako da se sastoji od njima poznatih gramatičkih struktura i vokabulara (korišten je samo nominativ i akuzativ te prezent glagola biti i imati). U prvom zadatku zadani su im imenica i po dva pridjeva te su koristeći zadanu imenicu i pridjeve trebali završiti rečenicu tipa To je... Ukupno su trebali završiti 25 takvih rečenica. U drugom zadatku zadani su im imenica i tri pridjeva te su koristeći tu imenicu i pridjeve trebali završiti rečenicu tipa To je... Ukupno su trebali završiti 6 takvih rečenica. Budući da je riječ o nominativu jednine, u prvom i drugom zadatku korištene su samo imenice ženskog roda da bi se izbjegli problemi i pitanja koja bi mogla proizaći iz upotrebe ili neupotrebe određenog oblika pridjeva uz imenice muškog roda. Radi sustavnosti korištena je samo jednina. U trećem zadatku ispitanici su 15 puta trebali odabrati rečenicu koju smatraju ispravnom, a rečenice se razlikuju prema redoslijedu pridjeva ispred imenice. Riječ je o rečenicama u kojima imenici prethode dva pridjeva. U četvrtom zadatku trebali su 10 puta odabrati rečenicu koju smatraju ispravnom, a rečenice se razlikuju prema redoslijedu pridjeva ispred imenice. Riječ je o rečenicama u kojima imenici prethode tri pridjeva. U trećem i četvrtom zadatku korišten je glagol imati i akuzativ. Budući da ispitanici na razini A1.1 uče samo imeničku deklinaciju, pazilo se da se pridjevski padežni nastavci podudaraju s imeničkim padežnim nastavcima, dakle muški rod korišten je samo u množini da (ne)poznavanje pravila o živosti ne bi utjecalo na rezultate, dok je ženski rod korišten i u jednini i u množini. Zadatci su osmišljeni tako da su mogući samo jednoznačni odgovori, što je potvrđeno testiranjem kontrolne skupine. Iznimka je četvrti zadatak u kojem su korištene međusobno susjedne značenjske kategorije pridjeva (slika 2) te su zamijene redoslijeda donekle moguće, no cilj zadatka bio je provjeriti imaju li ispitanici odstupanja pri nizanju pridjeva koji pripadaju međusobno nesusjednim kategorijama.

REZULTATI

\subsection{Prvi zadatak}

U prvom zadatku ispitanici su trebali završiti rečenicu koristeći zadanu imenicu i dva pridjeva, npr. zadana im je bila imenica bilježnica te pridjevi tipična i školska. Na slici 3 prikazano je koliko je svaki od ispitanika u skupini ispitanika koji su bili na A1.1 razini poznavanja HJ2 napravio odstupanja u nizanju pridjevnih modifikatora. Ukupno 6 
ispitanika iz te skupine, od 29 ispitanika, odgovorilo na sva pitanja bez odstupanja (govornici francuskoga, ukrajinskoga, korejskoga (2) i engleskoga (2)), dok nema ni jednog ispitanika koji je u svim odgovorima imao odstupanja, međutim najveći broj odstupanja u tom zadatku je 24, tj. 96\%, koliko ih je imao jedan ispitanik, koji je govornik španjolskoga. Prosječan broj odstupanja je 9,62 na ukupno 25 pitanja, dok je standardna devijacija 7,20, što upućuje na veliku raznolikost u broju odstupanja, a što je vidljivo i iz slike 2. Prosječna riješenost prvog zadatka u ovoj skupini ispitanika je 61,52\%, a ne postoji ni jedno pitanje na koje su svi ispitanici odgovorili bez odstupanja. Kod 13 ispitanika iz ove skupine (44,82\% ispitanika) pojavili su se postponirani pridjevi i tu je većinom riječ o govornicima španjolskog jezika. Ispitanik s najvećim brojem odstupanja postponirao je pridjeve u ukupno 96 \% zadatka (nije bilo moguće uočiti sustavnost u njihovu redoslijedu).

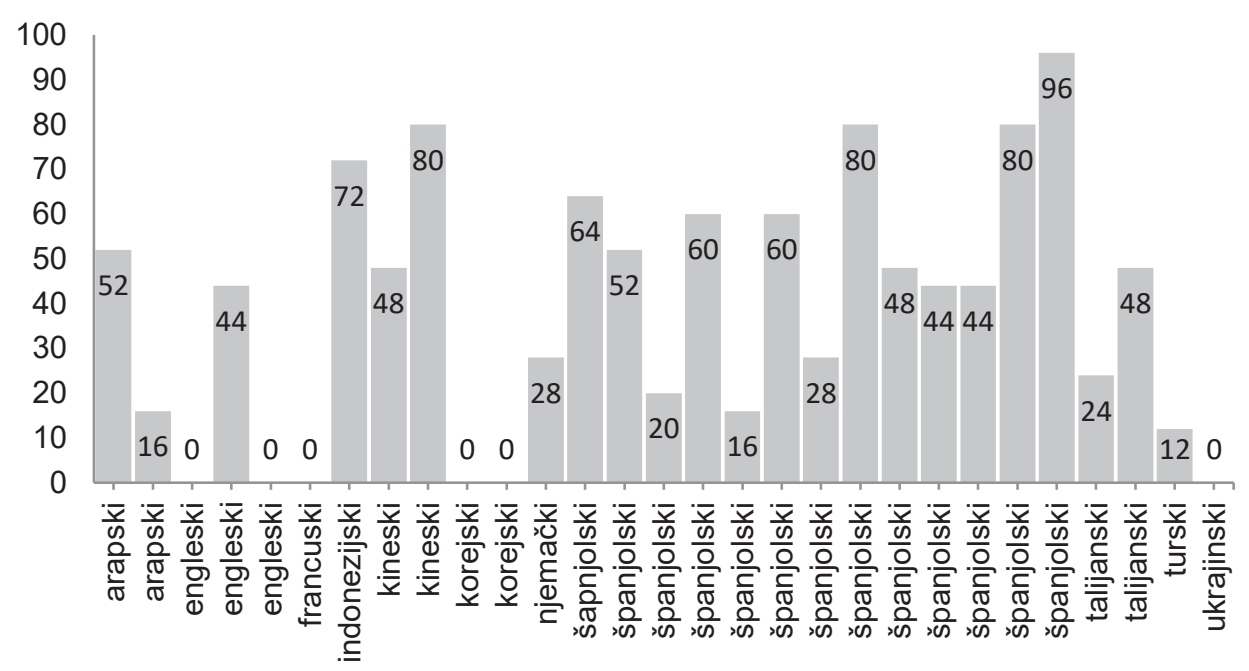

Slika 3: Riješenosti prvog zadatka (količina odstupanja u \%) po ispitaniku u skupini ispitanika na razini A1.1 poznavanja HJ2

Skupina ispitanika koji su poznavali HJ2 na razini B2.2 postigla je prosječnu riješenost prvog zadatka od 91,6\%. Međutim tek je 4 ispitanika od njih 10 u potpunosti riješilo zadatak bez odstupanja. Najveći broj odstupanja imao je, iznenađujuće, govornik poljskog, ukupno 6. Prosječan broj odstupanja po ispitaniku je 2,1, a standardna devijacija je 2,23. Na 14 pitanja svi ispitanici iz ove skupine odgovorili su bez odstupanja. Ni jedan ispitanik nije postponirao pridjeve. 


\subsection{Drugi zadatak}

U drugom zadatku ispitanici su trebali završiti rečenicu koristeći zadanu imenicu i tri pridjeva, npr. zadana im je bila imenica cipela te pridjevi dobra, crna i ženska. Na slici 4 prikazano je koliko je svaki od ispitanika u skupini ispitanika koji su bili na A1.1 razini poznavanja HJ2 napravio odstupanja u nizanju pridjevnih modifikatora. Ukupno 5 ispitanika iz te skupine, od 29 ispitanika, odgovorilo je na sva pitanja bez odstupanja (govornici francuskoga, ukrajinskoga, turskoga i engleskoga (2)), a 6 ispitanika imalo je odstupanja je u svim pitanjima (20,68\%). Prosječan broj odstupanja je 3,06 na ukupno 6 pitanja, dok je standardna devijacija 2,23 što upućuje na veliku raznolikost u broju odstupanja, a što je vidljivo i iz slike 3. Prosječna riješenost drugog zadatka u ovoj skupini ispitanika je 48,51\%, a ne postoji ni jedno pitanje na koje su svi ispitanici odgovorili bez odstupanja. Kod 10 ispitanika (34,48\% ispitanika) pojavili su se pridjevi postponirani imenici i tu je većinom riječ o govornicima španjolskog jezika.

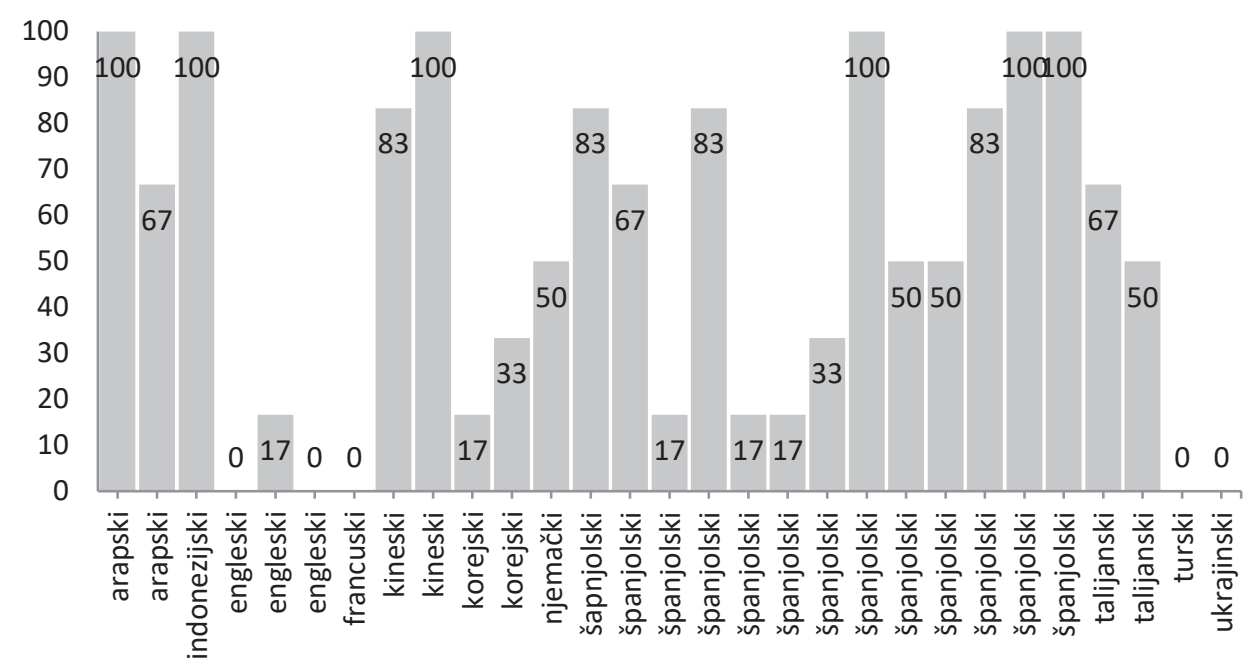

Slika 4: Riješenosti drugog zadatka (količina odstupanja u \%) po ispitaniku u skupini ispitanika na razini A1.1 poznavanja HJ2

Kada je riječ o skupini ispitanika koji su poznavali HJ2 na razini B2.2, može se primijetiti da je postigla bolje rezultate nego skupina ispitanika koji su poznavali HJ2 na razini A1.1, no, zanimljivo, ti su rezultati tek neznatno bolji. Prosječna riješenost drugog zadatka u ovoj skupini ispitanika je 68,33\%. Tek je 1 ispitanik, od ukupno 10 ispitanika, odgovorio na sva pitanja bez odstupanja, a najveći broj odstupanja, zapravo u svim odgovorima, imao je, iznenađujuće, govornik poljskoga. Prosječan broj odstupanja po ispitaniku je 1,9, a standardna devijacija je 1,59. Ne postoji pitanje na koje su svi ispitanici odgovorili bez odstupanja. Ni jedan ispitanik nije postponirao pridjeve. 


\subsection{Treći zadatak}

U trećem zadatku ispitanici su trebali odabrati rečenicu koju smatraju ispravnom, a rečenice su se razlikovale prema redoslijedu dvaju pridjeva ispred imenice, npr. zadane su im bile rečenice Baka ima ozbiljne zdravstvene probleme. i Baka ima zdravstvene ozbiljne probleme. Na slici 5 prikazano je koliko je svaki od ispitanika u skupini ispitanika koji su bili na A1.1 razini poznavanja HJ2 napravio odstupanja u odabiru. Ukupno 7 ispitanika iz te skupine ispitanika, od ukupno 29, odgovorilo je na sva pitanja bez odstupanja (govornici francuskoga, ukrajinskoga, engleskoga (2), španjolskoga, turskoga, arapskoga), a nijedan ispitanik nije imao odstupanja u svim pitanjima. Najveći broj odstupanja u tom zadatku je 12, od 15 pitanja, koliko je imao jedan govornik kineskoga. Prosječan broj odstupanja je 3,41 na ukupno 15 pitanja, dok je standardna devijacija (prosječno odstupanje od prosječnog broja odstupanja) 3,78. Prosječna riješenost trećeg zadatka u ovoj skupini ispitanika je 77,24\%, a ne postoji ne postoji ni jedno pitanje na koje su svi ispitanici odgovorili bez odstupanja.

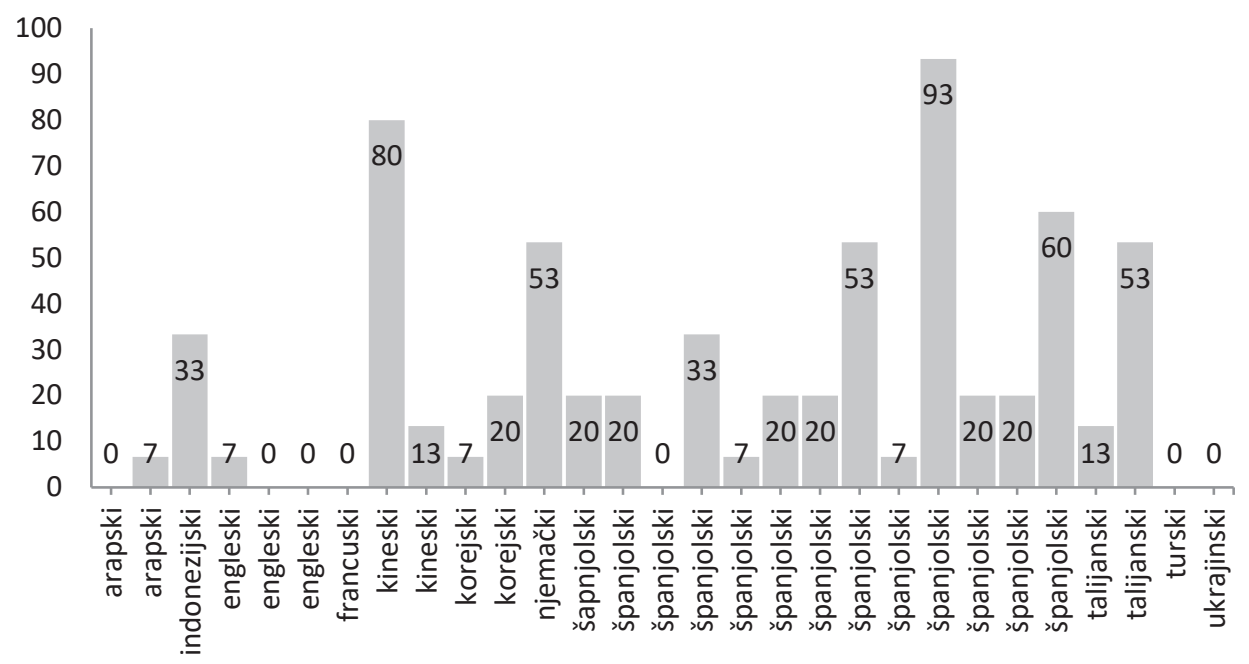

Slika 5: Riješenosti trećeg zadatka (količina odstupanja u \%) po ispitaniku u skupini ispitanika na razini A1.1 poznavanja HJ2

Skupina ispitanika koji su poznavali HJ2 na razini B2.2 postigla je bolje rezultate te su postigli prosječnu riješenost trećeg zadatka od 96,67\%. Samo su 2 ispitanika imala odstupanja (govornik albanskoga napravio je 4, a govornik poljskog 1 odstupanje). Prosječan broj odstupanja po ispitaniku je 0,5 , a standardna devijacija je 1,26. 


\section{4 Četvrti zadatak}

U četvrtom zadatku ispitanici su trebali odabrati rečenicu koju smatraju ispravnom, a rečenice su se razlikovale prema redoslijedu triju pridjeva ispred imenice, npr. zadane su im bile rečenice Imam odličnu sportsku novu informaciju., Imam sportsku novu odličnu informaciju., Imam novu odličnu sportsku informaciju., Imam novu sportsku odličnu informaciju. te Imam odličnu novu sportsku informaciju. Na slici 6 prikazano je koliko je svaki od ispitanika u skupini ispitanika koji su bili na A1.1 razini poznavanja HJ2 napravio odstupanja u odabiru. Prosječan broj odstupanja je 5,79 na ukupno 10 pitanja, dok je standardna devijacija (prosječno odstupanje od prosječnog broja odstupanja) 2,54. Prosječna riješenost četvrtog zadatka u ovoj skupini ispitanika je $42,06 \%$, a ne postoji ni jedno pitanje na koje su svi ispitanici odgovorili bez odstupanja.

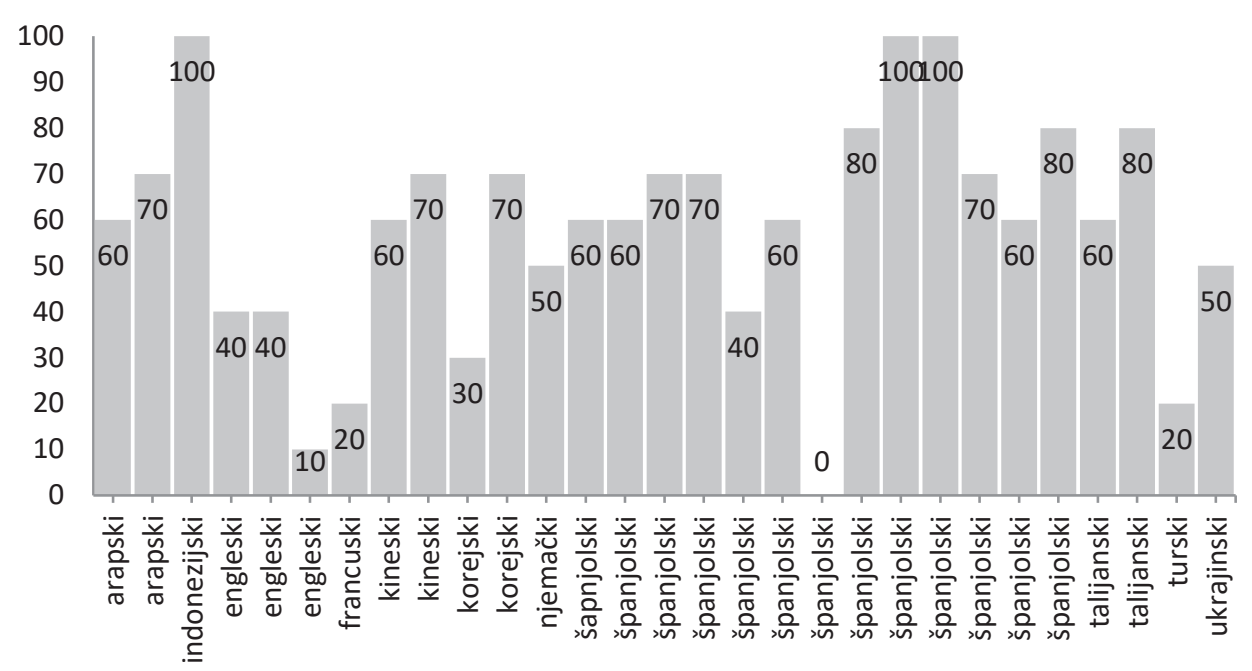

Slika 6: Riješenosti četvrtog zadatka (količina odstupanja u \%) po ispitaniku u skupini ispitanika na razini A1.1 poznavanja HJ2

Skupina ispitanika koji su poznavali HJ2 na razini B2.2 nije postigla znatno bolje rezultate te su postigli prosječnu riješenost četvrtog zadatka od 50,00 \%. Ni jedan ispitanik nije imao odstupanja u svim pitanjima, ali ni jedan ispitanik nije na sve odgovorio bez odstupanja (najveći broj odstupanja je 8 (govornik albanskoga), a najmanji 2 (govornik poljskoga)). Prosječan broj odstupanja po ispitaniku je 5, a standardna devijacija je 2 . 


\subsection{Sažetak rezultata istraživanja}

U tablici 4 usporedno su prikazani rezultati koje su u sva četiri zadatka postigle obje grupe ispitanika. Iz tih rezultata može se vidjeti da su ispitanici imali odstupanja u svim zadatcima, neovisno o razini poznavanja $\mathrm{HJ} 2$ te da je skupina ispitanika koja poznaje $\mathrm{HJ} 2$ na razini A1.1 sustavno postigla lošije rezultate od skupine ispitanika koja poznaje HJ2 na razini B2.2, što je u potpunosti očekivano. Međutim, ni jedan ispitanik, neovisno o razini poznavanja HJ2, nije sve zadatke riješio bez odstupanja. Nadalje, iz tablice 4 može se vidjeti da je broj odstupanja veći u zadatcima u kojima se provjerava nizanje triju pridjevnih modifikatora te da ispitanici više odstupaju u zadatcima u kojima trebaju proizvesti nego u onima u kojima trebaju prepoznati pravilan redoslijed pridjevnih modifikatora. Također, iz rezultata je vidljivo da se kod ispitanika koji su hrvatski poznavali na razini A1.1, a materinski jezik im je španjolski, postoji tendencije postponiranja pridjevnih modifikatora, a što je pak posljedica utjecaja španjolskoga.

Tablica 4: Prosječna riješenost zadataka po razinama poznavanja HJ2

\begin{tabular}{|c|c|c|}
\hline \multirow{2}{*}{ zadatak } & \multicolumn{2}{|c|}{ prosječna riješenost } \\
\cline { 2 - 3 } & razina A1.1 & razina B2.2 \\
\hline 1 & $61,52 \%$ & $91,60 \%$ \\
\hline 2 & $48,51 \%$ & $68,53 \%$ \\
\hline 3 & $77,24 \%$ & $96,67 \%$ \\
\hline 4 & $42,06 \%$ & $50,00 \%$ \\
\hline
\end{tabular}

\section{8}

\section{RASPRAVA}

Hipoteza od koje kreće istraživanje opisano u ovom radu pretpostavlja da govornici HJ2 nemaju odstupanja pri nizanju pridjevnih modifikatora u složenim imenskim skupinama. Hipoteza je tako oblikovana zbog toga što se u priručnicima za učenje HJ2 taj redoslijed ne objašnjava, a poučavatelji HJ2 u ne navode da govornici HJ2 imaju sustavna odstupanja. Rezultati ovog istraživanja, međutim, pokazuju da govornici HJ2, za razliku od izvornih govornika hrvatskoga, ipak odstupaju u nizanju pridjevnih modifikatora u složenim imenskim skupinama pa početna hipoteza ovog istraživanja nije potvrđena.

Iz činjenice da u nizanju pridjevnih modifikatora u složenim imenskim skupinama odstupaju ne samo ispitanici na niskoj razini poznavanja HJ2 (A1.1) nego i oni na višoj razini (B2.2), tj. iz činjenice da imaju odstupanja ne samo oni koji tek počinju učiti HJ2 nego i oni koji su hrvatskom jeziku već duže izloženi, može se zaključiti da se redoslijed pridjevnih modifikatora u složenim imenskim skupinama ne može jednostavno usvojiti uslijed dugotrajnije izloženosti jeziku, nego da je potrebno i eksplicitno poučavanje. 
Rezultati istraživanja pokazuju i da je broj odstupanja koji ispitanici čine u nizanju pridjevnih modifikatora u složenim imenskim skupinama raste s povećanjem broja pridjeva koji se nalaze u imenskoj skupini. Takvi rezultati su očekivani jer veći broj pridjevnih modifikatora povećava značenjsku složenost imenske skupine. Međutim, taj rezultat može se opisati i kao uvjetovan učestalošću složenih imenskih skupina s više modifikatora, tj. činjenicom da su takvim imenskim skupinama govornici HJ2 rijetko izloženi. Pretraživanje korpusa $h r W a C$, kao što pokazuje slika 1, pokazuje da je učestalost složenih imenskih skupina s tri pridjevna modifikatora znatno manja nego učestalost složenih imenskih skupina s dva pridjevna modifikatora, a učestalost složenih imenskih skupina s više od tri pridjevna modifikatora gotovo je zanemariva. Međutim, činjenica da izvorni govornici (kontrolna skupina) nemaju odstupanja ni kada je riječ o imenskim skupinama s dva ni kada je riječ o imenskim skupinama s tri pridjevna modifikatora, pokazuje da učestalost konstrukcije nije čimbenik koji (u potpunosti) može objasniti činjenicu da je porast odstupanja u proizvodnji složenih imenskih skupina s više pridjevnih modifikatora proporcionalan broju pridjevnih modifikatora u složenoj imenskoj skupini.

Obje skupine ispitanika imale su najviše odstupanja u zadatku u kojem su trebale odabrati prihvatljivu rečenicu u kojoj se nalazi imenska skupina s tri pridjevna modifikatora (4. zadatak). Međutim, ako se detaljnije usporede rezultati koji su obje skupne postigle, može se primijetiti da je skupina ispitanika koji su poznavali hrvatski na razini A1.1 imala znatno više odstupanja u kojima su prihvatljivim smatrali zamijene položaja pridjevnih modifikatora koji ne pripadaju međusobno susjednim značenjskim kategorijama pridjeva na slici 2. Skupina ispitanika koji su bili na B2.2 razini poznavanja HJ2 imala je znatno manji broj takvih odstupanja, što ide u prilog tvrdnji da se redoslijed pridjevnih modifikatora dijelom može usvojiti (unatoč činjenici da su takve skupine razmjerno neučestale). Ispitanici koji su izvorni govornici u nijednom slučaju nisu zamjenjivali položaj pridjevnih modifikatora koji pripadaju međusobno nesusjednim kategorijama.

Kada je riječ o utjecaju prvog jezika na odstupanja koja su ispitanici činili, ne može se donijeti ikakav konkretniji zaključak jer nije uočena sustavnost u postignutim rezultatima. Međutim, vidljivo je da ispitanici kojima je materinski jezik španjolski, a na razini A1.1 su poznavanja HJ2, tj. tek ga počinju učiti, postoji znatna tendencija postponiranja pridjevnih modifikatora, a što je posljedica utjecaja španjolskog. Međutim, čak i kada su bili postponirani, pridjevni modifikatori nisu slijedili pravila o nizanju.

Pitanje koje rezultati ovog istraživanja otvaraju tiče se univerzalnosti redoslijeda pridjevnih modifikatora u složenim imenskim skupinama. Prema literaturi moglo bi se pretpostaviti da bi redoslijed pridjevnih modifikatora mogao biti temeljen na istim principima u međusobno različitim i nepovezanim jezicima (npr. pridjevi koji označavaju nepromjenjivo svojstvo stoje bliže imenici osim u hrvatskome i u engleskome (Radden i Dirven 2007), ali i u azijskom jeziku qiang (LaPolla i Huang 2004)). Međutim, ako bi princip na kojem se temelji redoslijed pridjevnih modifikatora u složenim imenskim skupinama u načelu bio univerzalan, bilo bi za očekivati da govornici HJ2 nemaju odstupanja pri 
nizanju pridjevnih modifikatora, iako ih tomu nitko nije eksplicitno poučio. Međutim, rezultati do kojih se u ovom istraživanju došlo, a koji pokazuju da govornici HJ2 imaju odstupana pri nizanju pridjevnih modifikatora u složenim imenskim skupinama, pa čak i govornici koji pripadaju jezicima koji su srodni hrvatskome, npr. poljski, idu u prilog tvrdnji da princip nizanja pridjevnih modifikatora nije jezična univerzalija, već je i u nekoj mjeri jezičnospecifično obilježje. Drugim riječima, da je princip nizanja pridjevnih modifikatora u složenim imenskim skupinama jezična univerzalija, govornici HJ2 u tome ne bi imali odstupanja. Naravno, ovdje su potrebna puno opširnija istraživanja, posebice kontrastivna istraživanja semantičkih klasifikacija pridjeva u što većem broju međusobno srodnih, ali i, što je važnije, međusobno nesrodnih jezika.

\section{9}

\section{ZAKLJUČAK}

U ovom radu istraživanjem provedenim među 39 ispitanika koji su učili HJ2 na razinama A1.1 i B2.2 te među 10 izvornih govornika hrvatskoga pokušalo se doći do odgovora na dva temeljna pitanja. Prvo pitanje bilo je imaju li govornici HJ2 odstupanja pri nizanju pridjevnih modifikatora u složenim imenskim skupinama. Rezultati istraživanja jasno pokazuju da je odgovor na to pitanje potvrdan, tj. netočnom se pokazala početna pretpostavka da govornici HJ2 nemaju odstupanja pri nizanju pridjevnih modifikatora u složenim imenskim skupinama (pretpostavka je tako oblikovana zbog toga što se redoslijed u nastavi ne poučava te poučavatelji HJ2 ne navode da govornici HJ2 imaju sustavna odstupanja). Drugo pitanje na koje se pokušalo odgovoriti ovim istraživanjem je treba li u nastavu HJ2 uključiti eksplicitno poučavanje nizanja pridjevnih modifikatora u složenim imenskim skupinama. Rezultati jasno pokazuju da odstupanja pri nizanju pridjevnih modifikatora imaju i ispitanici koji tek počinju učiti HJ2 kao i oni koji ga uče već duže vrijeme pa je odgovor na to pitanje također potvrdan. Zaključak do kojeg se dolazi je sljedeći - budući da govornici HJ2 imaju odstupanja pri nizanju pridjeva u složenoj imenskoj skupini, tomu ih treba i poučiti.

Takav zaključak otvara, međutim, pitanje razine poznavanja HJ2 na kojoj bi bilo potrebno i opravdano eksplicitno poučavati taj sadržaj. Budući da pretraživanja korpusa pokazuju da je učestalost složenih imanskih skupina s više pridjevnih modifikatora niska, budući da pravila o nizanju pridjevnih modifikatora često nisu dosljedna ili nisu dovoljno dobro opisana te budući da se broj odstupanja u nizanju pridjevnih modifikatora u složenim imenskim skupinama smanjuje porastom razine poznavanja $\mathrm{HJ} 2$, to bi poučavanje trebalo biti prisutno tek na višim razinama poučavanja HJ2. Također, to bi poučavanje trebalo biti eksplicitno tek kad se za tim pokaže potreba, npr. kada govornik HJ2 u konkretnoj komunikacijskoj situaciji proizvede odstupanje u redoslijedu pridjeva u složenoj imenskoj skupini, i to tek na razini objasnidbenog i obavijesnog poučavanja. Eksplicitno uvježbavanje redoslijeda pridjevnih modifikatora u složenim imenskim skupinama 
opravdano bi bilo tek u nastavi u kojoj se pokaže potreba za tim, bilo zbog sustavnih odstupanja koji poučavani čine ili zbog specifičnog jezičnog sadržaja koji se poučava. Svakako, informacije o redoslijedu pridjevnih modifikatora u složenim imenskim skupinama morale bi biti dostupne i jasno objašnjene u gramatičkim pregledima namijenjenim kako onima koji HJ2 uče tako i onima koji ga poučavaju.

\section{BIBLIOGRAFIJA}

BAREŠIĆ, Jasna (2010) Dobro došli 1 - udžbenik i rječnik za učenje hrvatskoga jezika za strance. Zagreb: Školska knjiga.

BARIĆ, Eugenija/Mijo LONČARIĆ/Dragica MALIĆ/Slavko PAVEŠIĆ/Mirko PETI/ Vesna ZEČEVIĆ/Marija ZNIKA (1997) Hrvatska gramatika. Zagreb: Školska knjiga.

BELAJ, Branimir/Branko KUNA (2013) O kognitivnim temeljima položaja modifikatora, determinatora i kvantifikatora u imenskoj sintagmi. Rasprave Instituta za hrvatski jezik i jezikoslovlje 39 (2), 311-344.

BELAJ, Branimir/Darko MATOVAC (2015) On article-like use of indefinite determiners jedan and neki in Croatian and other Slavic languages. Suvremena lingvistika 79 (1), $1-20$.

BELAJ, Branimir/Goran TANACKOVIĆ FALETAR (2014) Kognitivna gramatika hrvatskog jezika (knjiga prva): Imenska sintagma i sintaksa padeža. Zagreb: Disput.

ČILAŠ MIKULIĆ, Marica/Milvia GULEŠIĆ MACHATA/Dinka PASINI/Sanda Lucija UDIER (2006) Hrvatski za početnike 1: Udžbenik i rječnik (3. izd.). Zagreb: Hrvatska sveučilišna naklada.

DIXON, R. M. W. (2004) Adjective classes: A cross-linguistic typology. A. Y. Aikhenvald, R. M. W. Dixon (ur.), Adjective Classes: A Cross-Linguistic Typology. New York: Oxford University Press, Inc., 1-49.

DOWNING, Angela/Philip LOCKE (2006) English Grammar: A University Course (2. izd.). New York: Routledge.

EASTWOOD, John (2002) Oxford guide to English grammar (7. izd.). Oxford: Oxford University Press.

EISENBERG, Peter (2013) Grundriss der deutschen Grammatik, Band 2: Der Satz (4. izd.). Stuttgart: J. B. Metzler Verlag.

ENGEL, Urlich (1996) Deutsche Grammatik (3. izd.). Heidelberg: Julius Groos Verlag.

RAE (2010) Nueva gramática de la lengua española: Manual. Madrid: Asociación de Academias de la Lengua Española.

GREENBERG, Joseph H. (1966) Some universals of grammar with particular reference to the order of meaningful elements. J. H. GREENBERG (ur.), Universals of language (2. izd.). Cambridge, Massachusetts: The M.I.T. Press, 73-113. 
KOSOVAC, Vesna/Vida LUKIĆ (2011) Učimo hrvatski 1. Udžbenik i vježbenica s gramatikom. Zagreb: Školska knjiga, Centar za strane jezike.

LANGACKER, Ronald W. (1987) Foundations of Cognitive Grammar. Stanford: Stanford University Press.

LANGACKER, Ronald W. (1991) Foundations of Cognitive Grammar: Descriptive Application. Stanford: Stanford University Press.

LANGACKER, Ronald W. (2008) Cognitive Grammar: A Basic Introduction. New York: Oxford University Press, Inc.

LAPOLLA, Randy J./Chenglong HUANG (2004) Adjectives in Qiang. A. Y. Aikhenvald, R. M. W. Dixon (ur.), Adjective Classes: A Cross-Linguistic Typology. New York: Oxford University Press, Inc., 306-322.

MARKOVIĆ, Ivan (2010) Uvod u pridjev. Zagreb: Disput.

MARKOVIĆ, Ivan (2012) Uvod u jezičnu morfologiju. Zagreb: Disput.

PALIĆ, Ismail (2015) Rasprave iz sintakse i semantike. Sarajevo: Bosansko filološko društvo.

QUIRK, Randolph/Sidney GREENBAUM/Geoffrey LEECH/Jan SVARTVIK (1985) $A$ comprehensive grammar of the English language. London, New York: Longman.

RADDEN, Günter/René DIRVEN (2007) Cognitive English Grammar. Amsterdam, Philadelphia: John Benjamins Publishing Company.

RAGUŽ, Dragutin (1997) Praktična hrvatska gramatika. Zagreb: Medicinska naklada.

SILIĆ, Josip (1984) Od rečenice do teksta. Zagreb: SNL.

SILIĆ, Josip/Ivo PRANJKOVIĆ (2005) Gramatika hrvatskoga jezika za gimnazije i visoka učilišta. Zagreb: Školska knjiga.

\section{POVZETEK}

\section{Poučevati ali ne poučevati vrstni red pridevniških določil v sestavljenih samostalniških zvezah?}

Prispevek predstavlja rezultate empirične raziskave, katere namen je bil ugotoviti, ali govorci hrvaščine kot drugega ali tujega jezika (HJ2) delajo napake pri določanju vrstnega reda pridevniških določil v sestavljenih samostalniških zvezah, npr. sportska nova odlična majica 'športna nova odlična majica' namesto odlična nova sportska majica 'odlična nova športna majica'. V uvodnem, teoretičnem delu prispevka je na kratko predstavljena zgradba sestavljenih samostalniških zvez v hrvaškem jeziku. Teoretične trditve o vrstnem redu pridevniških določil v samostalniških zvezah smo preverili s korpusno analizo. Pri raziskovalnem delu smo izhajali iz predpostavke, da govorci HJ2 pri določanju vrstnega reda pridevniških določil v sestavljenih samostalniških zvezah ne delajo napak. Nezaznavanje napak pripisujemo dejstvu, da delovni zvezki in priročniki za učitelje HJ2 vrstnega reda pridevniških določil v sestavljenih samostalniških zvezah ne obravnavajo, učitelji 
HJ2 pa ne zaznavajo sistematičnih napak pri govorcih HJ2. Raziskavo smo izvedli med govorci HJ2 na jezikovnih ravneh A1.1 in B2.2. Rezultati kažejo, da ti govorci HJ2 napačno določajo vrstni red pridevniških določil v sestavljenih samostalniških zvezah, zato predlagamo, da se ta vsebina začne obravnavati pri pouku HJ2. V zadnjem delu prispevka predlagamo načine poučevanja vrstnega reda pridevniških določil, pri čemer upoštevamo pogostnost sestavljenih samostalniških zvez z več pridevniškimi določili.

Ključne besede: pridevniško določilo, vrstni red pridevniških določil, sestavljene samostalniške zveze, hrvaščina kot drugi in tuji jezik

\section{ABSTRACT}

\section{To teach or not to teach the ordering of adjectival modifiers in complex nominals?}

The paper presents an empirical study which aimed to investigate whether the speakers of Croatian as a Second and Foreign Language (CL2) make errors when ordering adjectival modifiers in complex nominals, e.g. sportska nova odlična majica 'a sports new great t-shirt' instead of odlična nova sportska majica 'a great new sports t-shirt'. In the introductory part of the paper, a brief, theory driven overview of the structure of complex nominals in the Croatian language is presented, and the claims about the order of adjectival modifiers in such nominals are verified by corpus research. The hypothesis from which the research presented in this paper starts is that the CL2 speakers do not make errors when ordering adjectival modifiers in complex nominals. This is because the CL2 textbooks and teaching manuals do not explain the order of adjectival modifiers in complex nominals and CL2 instructors do not indicate that CL2 speakers make systematic errors. However, the results of the survey, which was conducted among CL2 speakers at A1.1 and B2.2 levels, show that CL2 speakers do make errors when ordering adjectival modifiers in complex nominals. Consequently, the paper concludes that they should be taught how to order adjectival modifiers in complex nominals. Considering the frequency of complex nominals with multiple adjectival modifiers, recommendations on how to teach these are presented in the final part of the paper.

Keywords: adjectival modifier, ordering of adjectival modifiers, complex nominal, Croatian as a second and foreign language

\section{SAŽETAK}

U radu se prikazuje empirijsko istraživanje koje je za cilj imalo istražiti imaju li govornici hrvatskoga kao drugog i stranog jezika (HJ2) odstupanja pri nizanju pridjevnih modifikatora u složenim 
imenskim skupinama, npr. sportska nova odlična majica umjesto odlična nova sportska majica. U uvodnom dijelu rada donosi se kratak teorijski usmjeren pregled ustrojstva složene imenske skupine u hrvatskom jeziku te se iznesene tvrdnje o redoslijedu pridjevnih modifikatora u takvim imenskim skupinama provjeravaju pretraživanjem korpusa. U istraživanju se pak kreće od polazišne pretpostavke da govornici HJ2 nemaju odstupanja u nizanju pridjevnih modifikatora u složenim imenskim skupinama zbog toga što se u udžbenicima i priručnicima za učenje HJ2 redoslijed pridjevnih modifikatora u složenim imenskim skupinama ne objašnjava, a poučavatelji HJ2 ne navode da govornici HJ2 imaju sustavna odstupanja. Rezultati istraživanja, do kojih se došlo provođenjem upitnika među govornicima HJ2 na razini A1.1 i B2.2, pokazuju, međutim, da govornici HJ2 imaju odstupanja u nizanju pridjevnih modifikatora u složenim imenskim skupinama te se posljedično donosi zaključak da bi ih se tomu trebalo poučavati. Uzimajući u obzir učestalost složenih imenskih skupina s više pridjevnih modifikatora donose se preporuke o tome kako bi to poučavanje trebalo izgledati.

Ključne riječi: pridjevni modifikator, redoslijed pridjevnih modifikatora, složena imenska skupina, hrvatski kao drugi i strani jezik 